\title{
Biosynthetic Origin of the Isoprene Units in Chromenes of Piper aduncum (Piperaceae)
}

\author{
Ana C. Leite, ${ }^{a}$ Adriana A. Lopes, ${ }^{a}$ Massuo J. Kato, ${ }^{b}$ Vanderlan da S. Bolzani ${ }^{a}$ and Maysa Furlan ${ }^{*, a}$ \\ ${ }^{a}$ Instituto de Química, Universidade Estadual Paulista, 14801-970 Araraquara-SP, Brazil \\ ${ }^{b}$ Instituto de Química, Universidade de São Paulo, 05599-970 São Paulo-SP, Brazil
}

\begin{abstract}
Estudos metabólicos envolvendo a incorporação de $D$-glicose- $\left[1-{ }^{13} \mathrm{C}\right]$ em folhas de Piper aduncum (Piperaceae) mostraram que as vias do mevalonato (MVA) e da triose-piruvato (MEP) estão envolvidas na biossíntese da unidade isoprênica presente no 2,2-dimetil-2H-1-cromeno-6carboxilato de metila (1) e no 2,2-dimetil-8-(3'-metil-2'-butenil)-2H-1-cromeno-6-carboxilato de metila (2). O padrão de incorporação dos carbonos marcados com $D$-glicose-[1- $\left.{ }^{13} \mathrm{C}\right]$ destes cromenos foram determinados através de espectroscopia de $\mathrm{RMN}$ de ${ }^{13} \mathrm{C}$ quantitativo. Os resultados confirmaram que o compartimento biossintético de $\mathbf{1}$ e $\mathbf{2}$ pode ser o plastídio e/ou citosol, ou possivelmente um compartimento adicional, como o espaço entre a membrana e o plastídio.
\end{abstract}

Metabolic studies involving the incorporation of $\left[1-{ }^{13} \mathrm{C}\right]-D$-glucose into intact leaves of Piper aduncum (Piperaceae) have indicated that both the mevalonate (MVA) and the pyruvate-triose (MEP) non-mevalonate pathways are implicated in the biosynthesis of isoprene moieties present in methyl 2,2-dimethyl-2H-1-chromene-6-carboxylate (1) and methyl 2,2-dimethyl-8-(3'-methyl2'-butenyl)-2H-1-chromene-6-carboxylate (2). The pattern of incorporation of label from [1$\left.{ }^{13} \mathrm{C}\right]-D$-glucose into these chromenes was determined by quantitative ${ }^{13} \mathrm{C}$ NMR spectroscopy. The results confirmed that biosynthetic compartment of $\mathbf{1}$ and $\mathbf{2}$ could either be the plastid and/ or the cytosol or, possibly, an additional compartment such as the plastid inter-membrane space.

Keywords: Piper aduncum, chromenes, $\left[1-{ }^{13} \mathrm{C}\right]-D$-glucose, mevalonate pathway, $2-C$-methyl$D$-erythritol-4-phosphate pathway

\section{Introduction}

The isoprenoids constitute a large class of natural products comprising more than 29,000 compounds. ${ }^{1}$ In higher plants, isoprenoids play essential roles in membrane structure (sterols), redox chemistry (plastoquinones, ubiquinones), growth regulation (gibberellins, cytokinins, brassinosteroids and abscisic acid), defence mechanisms (phytoalexins) and free radical scavenging (carotenoids and tocopherols). ${ }^{2}$ The common building blocks of all isoprenoids, the so-called 'isoprene units', is derived from isopentenyl diphosphate (IPP) and dimethylallyl diphosphate (DMAPP). The biosynthesis of IPP can proceed via two different pathways, namely the longestablished mevalonic acid (MVA) and the 2-C-methyl$D$-erythritol-4-phosphate (MEP) pathways, the reaction sequence of which has been characterized. ${ }^{3}$ In plants, the MEP pathway appears generally operative for formation

*e-mail: maysaf@iq.unesp.br of monoterpenoids, diterpenoids, phytols and carotenoids. ${ }^{4-6}$ The key regulatory step of the MVA pathway involves reduction of 3-hydroxy-3-methylglutaryl CoA (HMG-CoA) to mevalonate, with this being catalysed by the cytosolic enzyme HMG-CoA reductase (HMGR). Plastidic IPP is derived, however, from MEP formed via the condensation of pyruvate and glyceraldehyde-3-phosphate (G3P) catalysed by 1-deoxy- $D$-xylulose-5-phosphate synthase (DXS). ${ }^{2,6}$ The two pathways to IPP are thus compartmentalized in the cytosol and the plastid, respectively. However, they may function in the formation of certain isoprenoids, in a cooperative process that results from metabolic cross-talk within the plastidic envelope membrane. ${ }^{2}$

Piper aduncum L. (Piperaceae) contains a number of chromenes that possess both anti-fungal and anti-tumour activities. ${ }^{7,8}$ Recently, the prenylation of methyl 2,2dimethyl-2H-1-chromene-6-carboxylate (1) to yield methyl 2,2-dimethyl-8-(3'-methyl-2'-butenyl)-2H-1-chromene-6carboxylate (2) has been reported. ${ }^{9}$ In the present work, the 
biosynthetic origins of the isoprene units present in $\mathbf{1}$ and 2, isolated from the leaves of $P$. aduncum, have been determined from feeding experiments with $\left[1-{ }^{13} \mathrm{C}\right]-D$ glucose as (a putative) substrate. Metabolic studies involving this labelled precursor have previously been shown to provide a powerful strategy for the quantitative assessment of the differential contribution of the two isoprenoid pathways in the biosynthesis of individual terpenes. ${ }^{10}$

\section{Experimental}

\section{Standards and chemicals}

${ }^{1} \mathrm{H}$ and ${ }^{13} \mathrm{C}$ NMR spectra were recorded in $\mathrm{CDCl}_{3}$ with a VARIAN INOVA 500 spectrometer. Chemical shift values were recorded relative to the $\delta_{\mathrm{H}}(7.24 \mathrm{ppm})$ and $\delta_{\mathrm{C}}(77.0$ ppm) signals of the predominantly deuterated solvent. Silica gel (70-230 and 230-400 mesh, Merck) and C18 silica gel (Merck) were used for column chromatography. The [1$\left.{ }^{13} \mathrm{C}\right]-D$-glucose (99\% isotopic abundance) was purchased from Sigma-Aldrich.

\section{Plant material}

Specimens of Piper aduncum L. were cultivated from seed under greenhouse conditions at the Institute of Chemistry, UNESP, Araraquara, SP, Brazil. Plant material was authenticated by Dr. Inês Cordeiro (Instituto de Botânica, São Paulo, SP, Brazil) and voucher specimen (Kato-57) has been deposited at the Herbário do Estado "Maria Eneyda P. Kaufmann Fidalgo" (São Paulo, SP, Brazil).

Administration of $\left[1-{ }^{13} C\right]-D$-glucose into young leaves from $P$. aduncum

350 young leaves (210 g), freshly excised from 3-4 month old plants, were placed separately in $2 \mathrm{~mL}$ Eppendorf tubes and each administered $100 \mu \mathrm{L}$ of a $0.1 \%$ solution of $\left[1-{ }^{13} \mathrm{C}\right]-D$-glucose in water at $25^{\circ} \mathrm{C}$ for $72 \mathrm{~h} .{ }^{11,12}$

\section{Extraction and isolation}

After incubation, the leaves were frozen in liquid $\mathrm{N}_{2}$ and subsequentially extracted with EtOAc $(2 \times 25 \mathrm{~mL})$, the solvent was removed by evaporation and the resulting crude extract (15.3 g) submitted to vacuum chromatography over silica gel (70-230 mesh) eluted with a hexane-EtOAc-MeOH in gradient elution. The EtOAc-soluble fraction obtained of the last fractionation was applied to a $\mathrm{C} 18$ silica gel column (Sorbent technologies-premium grade; 40-63 mm) and eluted with $\mathrm{MeOH}-\mathrm{H}_{2} \mathrm{O}(8: 2)$ to yield five fractions ( $A$ -
$E)$. Fraction $C(0.120 \mathrm{~g})$ was chromatographed twice over silica gel (230-400 mesh), eluting with hexane-acetone (9:1), to afford 1 (7.2 $\mathrm{mg})$ and 2 (3.5 $\mathrm{mg})$.

\section{Spectroscopy}

The ${ }^{1} \mathrm{H}$ and ${ }^{13} \mathrm{C}$ NMR spectra of samples of $\mathbf{1}$ and $\mathbf{2}$ obtained from incorporation experiments involving $\left[1-{ }^{13} \mathrm{C}\right]-D$-glucose as precursor or from field-grown plants $\left({ }^{13} \mathrm{C}\right.$ at natural abundance) were measured under identical conditions. The relative abundances of ${ }^{13} \mathrm{C}$ at individual carbon atoms in $\mathbf{1}$ and $\mathbf{2}$ were calculated from the integrals obtained from the labelled sample in comparison with those of the natural abundance sample (Table 1). The values were normalised with reference to an abundance value of $1.1 \%$ for the carbon with the lowest ${ }^{13} \mathrm{C}$ enrichment. The ${ }^{1} \mathrm{H}$ and ${ }^{13} \mathrm{C}$ NMR data obtained were compared with $1 \mathrm{D}$ and 2D NMR data reported previously. ${ }^{13,14}$

\section{Results and Discussion}

The relative contributions of the two alternative biosynthetic routes to the 'isoprene units' may be readily deduced from the labelling patterns of the $\mathrm{C} 5$ units of isoprenoids synthesised from $\left[1-{ }^{13} \mathrm{C}\right]-D$-glucose. Label derived from $\left[1-{ }^{13} \mathrm{C}\right]-D$-glucose should be located at $\mathrm{C}-2$ of acetyl CoA, and at C-3 of pyruvate and glyceraldehyde-3phosphate. Thus DMAPP arising from three C-2 labelled acetyl CoA molecules via the MVA pathway should be labelled at C-2, C-4 and C-5. In contrast, DMAPP derived from C-3 labelled pyruvate and glyceraldehyde-3-phosphate via the MEP pathway should be labelled at C-1 and C-5. ${ }^{15}$

Leaves of $P$. aduncum were administered with $\left[1-{ }^{13} \mathrm{C}\right]-$ $D$-glucose and incubated for $72 \mathrm{~h}$. The leaves were harvested and extracted as described in the experimental section. The fractionation of the EtOAc lead to the isolation of methyl 2,2-dimethyl-2H-1-chromene-6-carboxylate (1) and methyl 2,2-dimethyl-8-(3'-methyl-2'-butenyl)-2H-1-chromene-6carboxylate (2). The ${ }^{13} \mathrm{C}$ NMR spectra of $\mathbf{1}$ and $\mathbf{2}$ enriched with ${ }^{13} \mathrm{C}$ and that of a reference sample of $\mathbf{1}$ and $\mathbf{2}\left({ }^{13} \mathrm{C}\right.$ natural abundance) were measured in $\mathrm{CDCl}_{3}$ under identical conditions, and the relative enrichment at each position was calculated by assuming an abundance of $1.1 \%$ for the carbon with the lowest ${ }^{13} \mathrm{C}$-enrichment (Table 1).

The ${ }^{13} \mathrm{C}$ NMR spectrum of methyl 2,2-dimethyl-8(3'-methyl-2'-butenyl)-2H-1-chromene-6-carboxylate (2) biosynthesised from $\left[1-{ }^{13} \mathrm{C}\right]-D$-glucose showed significant enhancement of the signals at C-2', C-4' and C-5' (Table 1) indicating incorporation of label into the corresponding 'isoprene unit' via the MVA pathway as shown in Figure 1. In the pyran ring, however, 
Table 1. Position-specific relative abundance of ${ }^{13} \mathrm{C}$ in methyl 2,2-dimethyl-2H-1-chromene-6-carboxylate (1) and methyl 2,2-dimethyl-8-(3'-methyl-2'-butenyl)$2 \mathrm{H}$-1-chromene-6-carboxylate (2) isolated from Piper aduncum following incorporation of [1-13 $\mathrm{C}]$ - $D$-glucose into intact leaves

\begin{tabular}{|c|c|c|c|c|}
\hline \multirow[t]{2}{*}{ Carbons } & \multicolumn{2}{|c|}{ Chromene 1} & \multicolumn{2}{|c|}{ Chromene 2} \\
\hline & $\delta /(\mathrm{ppm})^{\mathrm{a}}$ & Relative enrichment $/(\%)^{\mathrm{b}}$ & $\delta /(\mathrm{ppm})^{\mathrm{a}}$ & Relative enrichment / $(\%)^{b}$ \\
\hline 2 & 77.4 & 1.1 & 77.3 & 1.1 \\
\hline 3 & 131.1 & 2.2 & 130.7 & 2.2 \\
\hline 4 & 121.7 & 4.4 & 122.1 & 4.4 \\
\hline 5 & 128.1 & 1.1 & 126.0 & 1.1 \\
\hline 6 & 122.5 & 3.3 & 122.0 & 3.3 \\
\hline 7 & 131.1 & 1.1 & 131.0 & 1.1 \\
\hline 8 & 116.1 & 2.2 & 129.2 & 2.2 \\
\hline $4 a$ & 120.6 & 2.2 & 120.4 & 2.2 \\
\hline $8 \mathrm{a}$ & 157.2 & 1.1 & 154.8 & 1.1 \\
\hline 9 and 10 & 28.3 & 8.8 & 28.3 & 8.8 \\
\hline 1 & - & - & 28.2 & 1.1 \\
\hline 2 ' & - & - & 121.9 & 3.3 \\
\hline $3^{\prime}$ & - & - & 132.4 & 1.1 \\
\hline 4 ' & - & - & 25.8 & 4.4 \\
\hline 5 & - & - & 17.9 & 2.2 \\
\hline $\mathrm{OCH}_{3}$ & 51.8 & 4.4 & 51.7 & 4.4 \\
\hline $\mathrm{C}=\mathrm{O}^{3}$ & 166.8 & 1.1 & 167.1 & 1.1 \\
\hline
\end{tabular}

${ }^{a}$ Chemical shift values referenced to $\mathrm{CDCl}_{3} \cdot{ }^{\mathrm{b}} \mathrm{Calculated}$ from the relative intensities of signals in the ${ }^{13} \mathrm{C}$ NMR spectra of the respective labelled and natural abundance sample.

enrichment at positions C-4, C-9 and C-10 was observed corresponding, respectively, to C-1 and C-5 of IPP derived from the MEP pathway. In chromenes $\mathbf{1}$ and $\mathbf{2}$, the two methyl groups $\mathrm{C}-9$ and $\mathrm{C}-10$ are enantiotopic and gave rise to a single ${ }^{13} \mathrm{C}-\mathrm{NMR}$ signal, displaying a relative enrichment of $8.8 \%$. In this case, the data did not provide information for the precise distribution of the label, but this did not interfere in the determination of the biosynthetic origin of the isoprene unit in pyran ring. The biosynthetic precursor of 2, i.e. methyl 2,2dimethyl-2H-1-chromene-6-carboxylate (1), presented a similar enrichment pattern in the pyran ring (Figure 1). Thus, signals at C-4, C-9 and C-10 of 1 were enhanced (Table 1) in accord with incorporation of
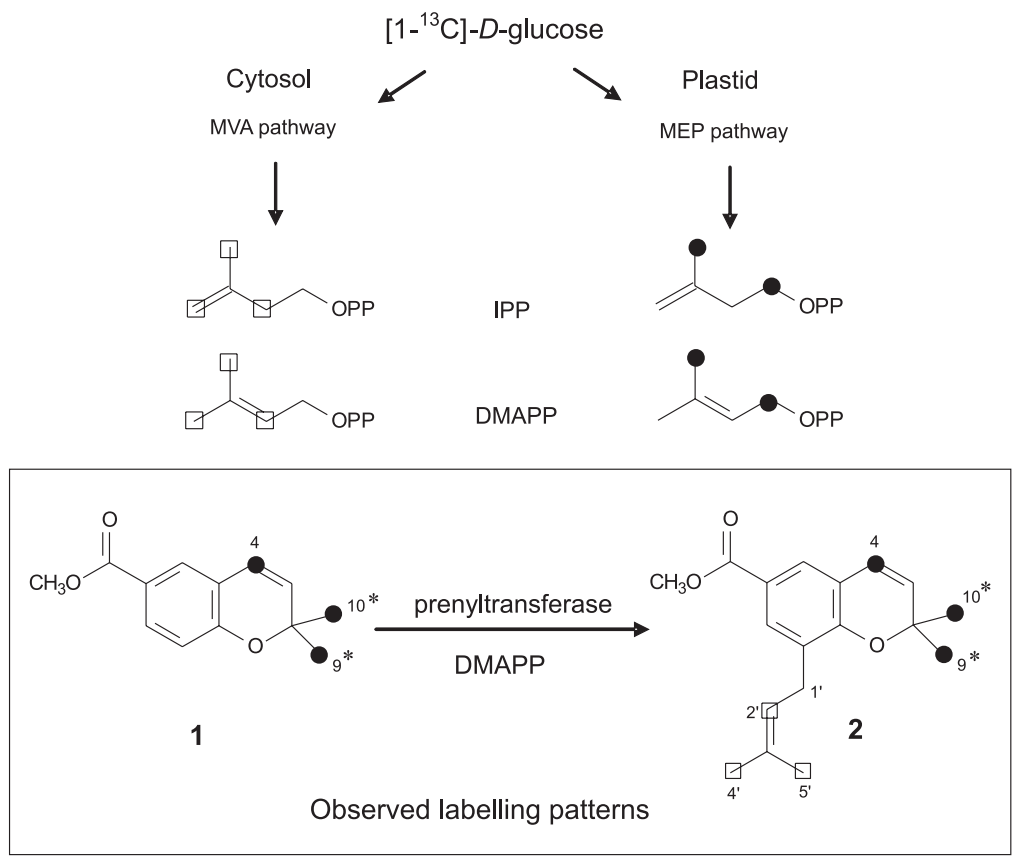

Figure 1. Predicted labelling patterns for IPP and DMAPP units synthesised from $\left[1-{ }^{13} \mathrm{C}\right]-D$-glucose via the mevalonate pathway (MVA) and the non-mevalonate (MEP). The insert shows the experimentally determined positions of label in methyl 2,2-dimethyl-2H-1-chromene-6-carboxylate (1) and methyl 2,2-dimethyl8-(3'-methyl-2'-butenyl)-2H-1-chromene-6-carboxylate (2) isolated from Piper aduncum following incorporation of [1-13 $\mathrm{C}]-D$-glucose into intact leaves. * enantiotopic groups. 
$\left[1-{ }^{13} \mathrm{C}\right]-D$-glucose via the MEP pathway. These data confirm that the initial prenylation of the $p$ hydroxybenzoic acid precursor of chromenes $\mathbf{1}$ and $\mathbf{2}$ occurred via MEP pathway (Figure 1). The aromatic and methoxyl carbons enrichments might be due to complex metabolic turnover of $\left[1-{ }^{13} \mathrm{C}\right]-D$-glucose with following statistical distribution of the carbon atoms in various positions of intermediates of carbohydrate metabolism. These enrichments corroborated their biosynthesis in plants showing the same build blocks of the prenyl units derived from the glycolysis and the Krebs cycle that use the phosphoenolpyruvate, pyruvic acid and acetyl CoA as intermediates.

\section{Conclusions}

The present work is in accord with various studies that have suggested the simultaneous operation of two separate biosynthetic routes to the IPP/DMAPP units present in some plant isoprenoids..$^{5,12,16-23}$ The prenylation of the $p$ hydroxybenzoic acid involved in the formation of the chromenes $\mathbf{1}$ and $\mathbf{2}$ occurred via MEP pathway, suggesting that it is compartmentalized in the plastid. On the other hand, the second prenylation step would be occurred in the cytosol by MVA pathway. The observation of mixed biosynthesis, with contributions from both MVA and the MEP pathways, implies that certain biosynthetic steps proceed in different compartments, and that specific intermediates traverse the chloroplast boundary. At the enzymatic level, this hypothesis would imply the presence of two DMAPP synthases located in the plastid and in the cytosol. In P. aduncum, a prenyltransferase has already been identified. ${ }^{9}$ This report constitutes the third example of the participation of DMAPP/ IPP moieties derived from both MVA and MEP in the prenylation of benzoic acid derivatives. ${ }^{11,12}$

\section{Acknowledgments}

This study was funded by grants provided by FAPESP (03/11524-9 and 05/57042-0), and was supported by the State of São Paulo Research Foundation (FAPESP) within the BIOTA/FAPESP Biodiversity Virtual Institute Program (www.biotasp.org.br). ACL and AAL thank FAPESP for providing their fellowship (05/54134-1) and scholarship (03/01867-6), respectively. MF, MJK, and VSB are grateful to $\mathrm{CNPq}$ for research fellowships.

\section{Supplementary Information}

${ }^{13} \mathrm{C}$ NMR spectra of $\mathbf{1}$ and $\mathbf{2}$ are available free of charge at http://jbcs.sbq.org.br, as PDF file.

\section{References}

1. Fukusaki, E.; Takeno, S.; Bamba, T.; Okumoto, H.; Katto, H.; Kajiyama, S.; Kobayashi, A.; Biosci., Biotechnol., Biochem. 2004, 68, 1988.

2. Enfissi, E. M. A.; Fraser, P. D.; Lois, L. M.; Boronat, A.; Schuch, W.; Bramley, P. M.; Plant Biotechnol. J. 2005, 3, 17.

3. Adam, K. P.; Thiel, R.; Zapp J.; Arch. Biochem. Biophys. 1999, 369, 127.

4. Hirai, N.; Yoshida, R.; Todoroki, Y.; Ohigashi, H.; Biosci., Biotechnol., Biochem. 2000, 64, 1448.

5. Umlauf, D.; Zapp, J.; Becker, H.; Adam, K. P.; Phytochemistry 2004, 65, 2463.

6. Bouvier, F.; Rahier, A.; Câmara, B.; Prog. Lipid. Res. 2005, 44, 357.

7. Baldoqui, D. C.; Kato, M. J.; Cavalheiro, A. J.; Bolzani, V. S.; Young, M. C. M.; Furlan, M.; Phytochemistry 1999, 51, 899.

8. Lago, J. H. G.; Ramos, C. S.; Casanova, D. C. C.; Morandim, A. D.; Bergamo, D. C. B.; Cavalheiro, A. J.; Bolzani, V. S.; Furlan, M.; Guimarães, E. F.; Young, M. C. M.; Kato, M. J.; J. Nat. Prod. 2004, 67, 1783.

9. Morandim, A. D.; Bergamo, D. C. B.; Kato, M. J.; Cavalheiro, A. J.; Bolzani, V. S.; Furlan, M.; Phytochem. Anal. 2005, 16, 282.

10. Eisenreich, W.; Bacher, A.; Arigoni, D.; Rohdich, F.; Cell. Mol. Life Sci. 2004, 61, 1401.

11. Bergamo, D. C. B.; Kato, M. J.; Bolzani, V. S.; Furlan, M.; J. Braz. Chem. Soc. 2005, 16, 1406.

12. Lopes, A. A.; Baldoqui, D. C.; López, S. N.; Kato, M. J.; Bolzani, V. S., Furlan, M.; Phytochemistry 2007, 68, 2053.

13. Moreira, D. D.; Guimarães, E. F.; Kaplan, M. A. C.; Phytochemistry 1998, 48, 1075.

14. Orjala, J.; Erdelmeier, C. A. J.; Wright, A. D.; Rali, T.; Sticher, O.; Phytochemistry 1993, 34, 813.

15. Rohmer, M.; Knani, M.; Simonin, P.; Sutter, B.; Sahm, H.; Biochem. J. 1993, 295, 517.

16. Schwender, J.; Seemann, M.; Lichtenthaler, H. K.; Rohmer, M.; Biochem. J. 1996, 316, 73.

17. Knoss, W.; Reuter, B.; Zapp, J.; Biochem. J. 1997, 326, 449.

18. Thiel, R.; Adam, K. P.; Zapp, J.; Becker, H.; Pharm. Pharmacol. Lett. 1997, 7, 103.

19. Adam, K. P.; Zapp J.; Phytochemistry 1998, 48, 953.

20. Barlow, A. J.; Becker, H.; Adam, K. P.; Phytochemistry 2001, $57,7$.

21. Hertewich, U.; Zapp, J.; Becker, H.; Adam, K. P.; Phytochemistry 2001, 58, 1049.

22. Thiel, R.; Adam, K. P.; Phytochemistry 2002, 59, 269.

23. Massé, G; Belt, S. T.; Rowland, S. J.; Phytochemistry 2004, 65, 1101.

Received: June 20, 2007

Web Release Date: December 6, 2007

FAPESP helped in meeting the publication costs of this article. 
Biosynthetic Origin of the Isoprene Units in Chromenes of Piper aduncum (Piperaceae)

Ana C. Leite, ${ }^{*}, a$ Adriana A. Lopes, ${ }^{a}$ Massuo J. Kato, ${ }^{b}$ Vanderlan da S. Bolzani ${ }^{a}$ and Maysa Furlan ${ }^{a}$

${ }^{a}$ Instituto de Química, Universidade Estadual Paulista, 14801-970 Araraquara-SP, Brazil

${ }^{b}$ Instituto de Química, Universidade de São Paulo, 05599-970 São Paulo-SP, Brazil

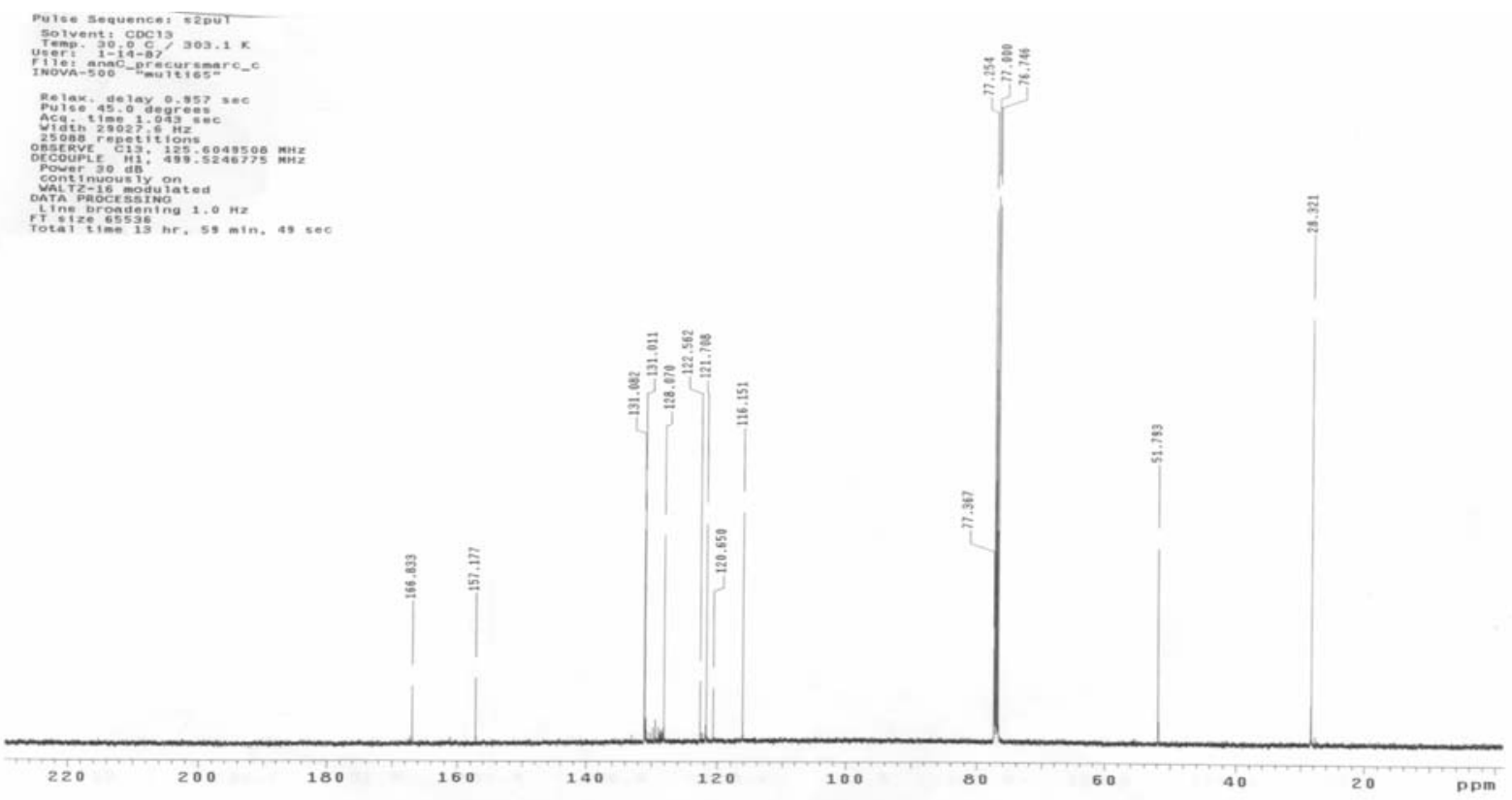

Figure S1. ${ }^{13} \mathrm{C}$ NMR spectrum of methyl 2,2-dimethyl-2H-1-chromene-6-carboxylate (1) (natural abundance sample, $\mathrm{CDCl}_{3}$ ).

*e-mail: acrisleite@gmail.com 
Pulses sequences: 52001

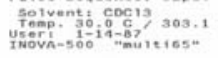

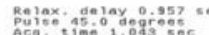

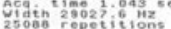

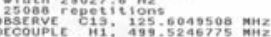

ponit so sous on

the

Totaiz

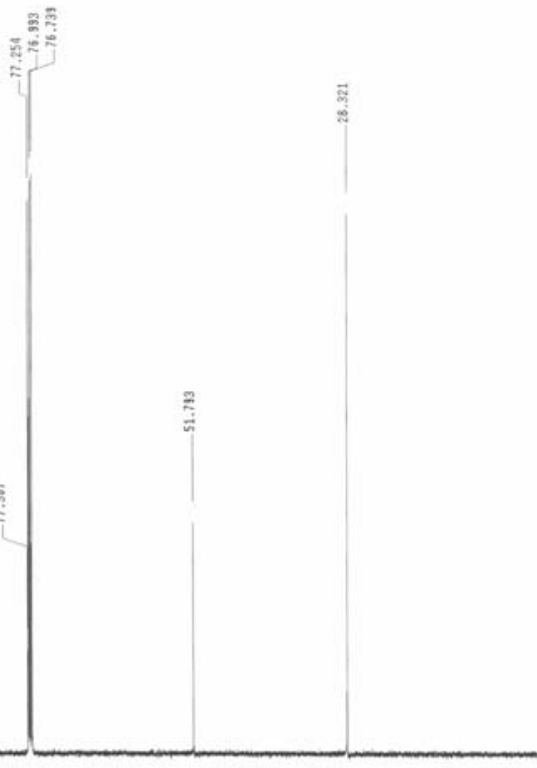

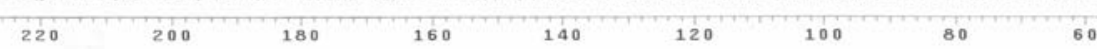

40

20

Figure S2. ${ }^{13} \mathrm{C}$ NMR spectrum of methyl 2,2-dimethyl-2H-1-chromene-6-carboxylate (1) (labelled sample, $\mathrm{CDCl}_{3}$ ).
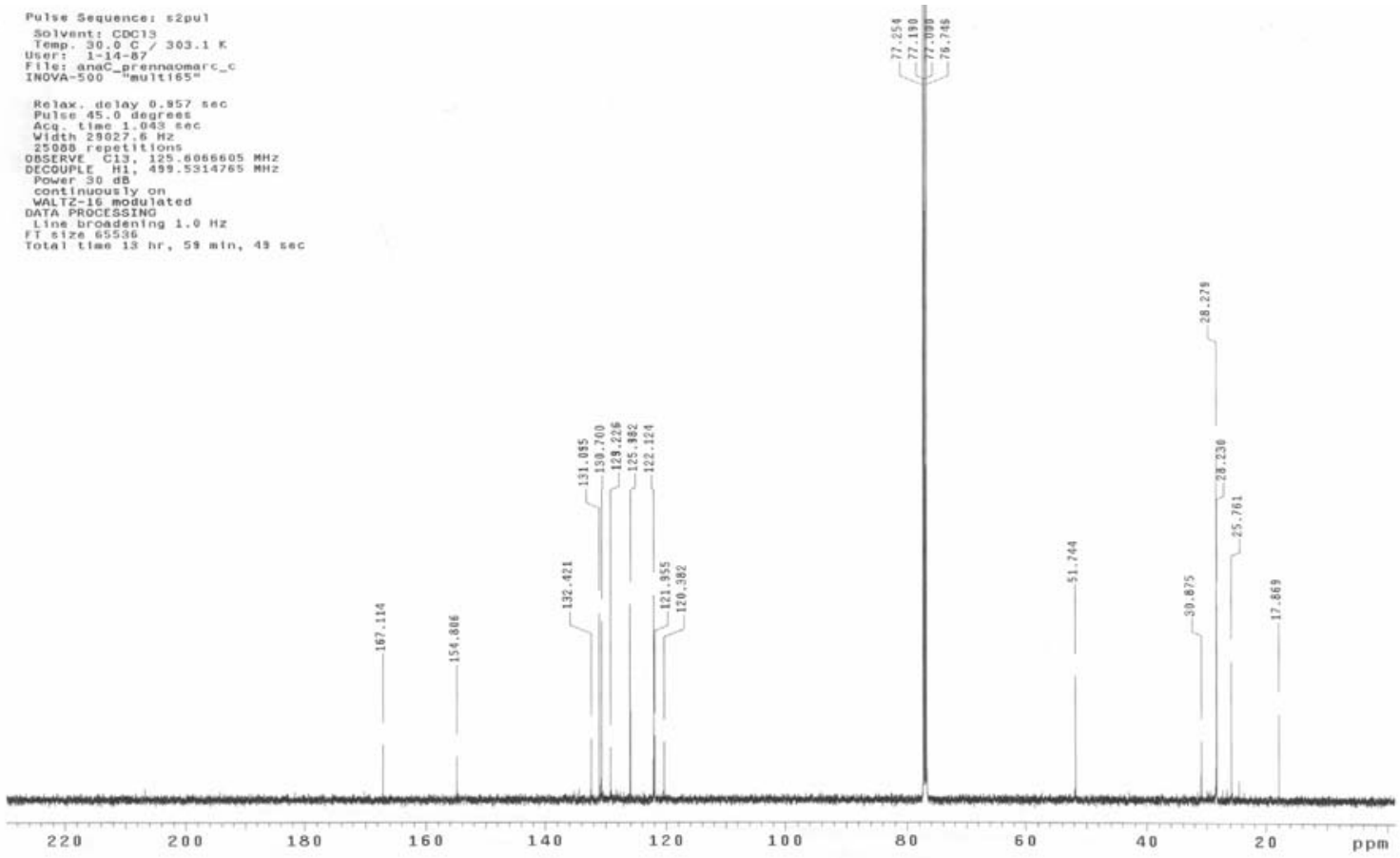

Figure S3. ${ }^{13} \mathrm{C}$ NMR spectrum of methyl 2,2-dimethyl-8-(3'-methyl-2'-butenyl)-2H-1-chromene-6-carboxylate (2) (natural abundance sample, CDCl $)$. 
furse sequences $=2 \mathrm{p}$

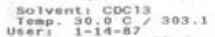

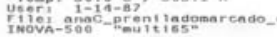

Relax delay $0.957=0$

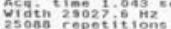

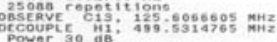

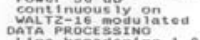

Prthizer

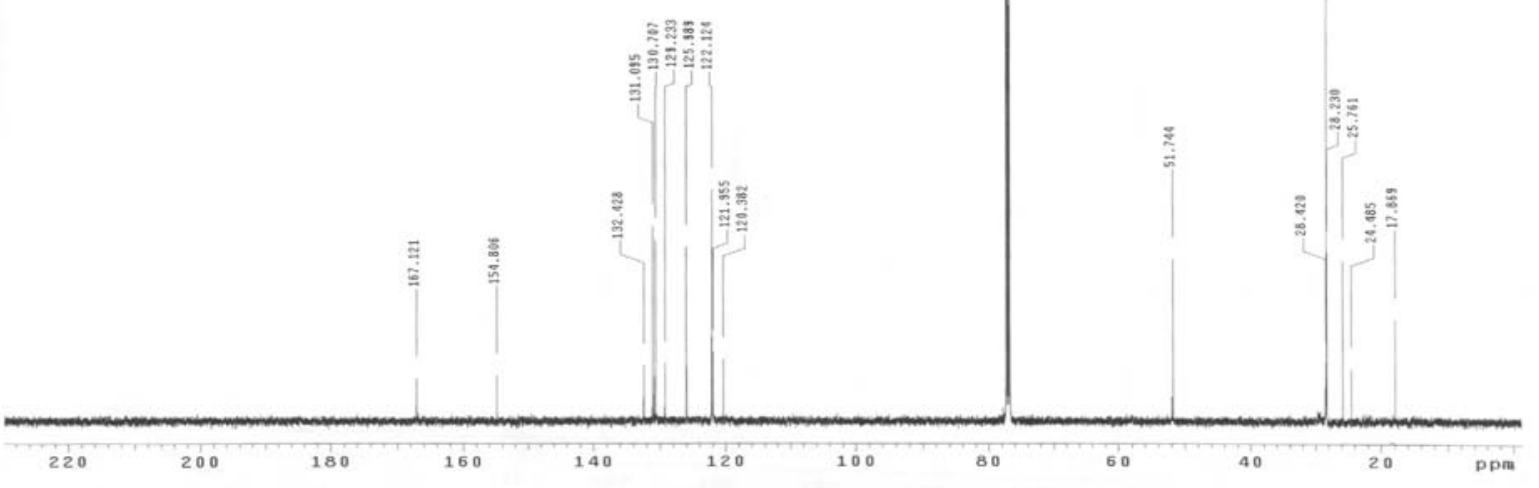

Figure S4. ${ }^{13} \mathrm{C}$ NMR spectrum of methyl 2,2-dimethyl-8-(3'-methyl-2'-butenyl)-2H-1-chromene-6-carboxylate (2) (labelled sample, CDCl ${ }_{3}$ ). 